\title{
THERMODYNAMIC ANALYSIS AND ECOLOGICAL EFFICIENCY OF A COMBINED CYCLE POWER PLANT
}

\author{
C. F. P. Santos, \\ ABSTRACT \\ R. F. S. Paulino, \\ C. E. Tuna, \\ The purpose of this article is to through the analysis of the first law of \\ thermodynamic for a combined cycle determines the ecological coefficient \\ of the same. This system consists of two gas turbines, two heat recovery \\ boilers and a steam turbine, having a total installed capacity of power \\ generation of $500 \mathrm{MW}$. This plant will be installed in a small town located \\ $180 \mathrm{~km}$ from São Paulo. This place was chosen based on technical aspects \\ by present proximity to the pipeline and transmission line, water availability \\ and other favorable environmental aspects of the project. The natural gas \\ that will serve as the plant's fuel will come from the Field of Mexilhão, \\ from the base of Caraguatatuba, and the water used for cooling will come \\ Universidade Estadual de São Paulo \\ Departamento de Energia \\ from the Paraíba do Sul River. \\ Faculdade de Engenharia de Guaratinguetá \\ Bairro Pedregulho \\ CEP 12516-410, Guaratinguetá, SP, Brasil \\ cfps89@gmail.com \\ Received: October 29, 2014 \\ Revised: November 30, 2014 \\ Accepted: December 30, 2014 \\ Keywords: combined cycle plant, thermodynamic, power plants, ecological \\ efficiency
}

\section{NOMENCLATURE}

$\mathrm{c}_{\mathrm{pn}} \quad$ fluid specific heat at constant pressure at the point $\mathrm{n}, \mathrm{J} /(\mathrm{kg} . \mathrm{K})$

CG combustion gases

E energy, $\mathrm{kW}$

$\mathrm{h}$ specific enthalpy, $\mathrm{kJ} / \mathrm{kg}$

$\dot{\mathrm{m}}_{\mathrm{n}} \quad$ mass flow of the fluid at the point $\mathrm{n}, \mathrm{kg} / \mathrm{s}$

M molar mass, $\mathrm{kg} / \mathrm{kmol}$

m mass, $\mathrm{kg}$

NG natural gas

$\mathrm{p}$ pressure, $\mathrm{MPa}$

$\mathrm{Q}_{\mathrm{i}} \quad$ low heat value of the natural gas, $\mathrm{kW} / \mathrm{kg}$

$\mathrm{T}_{\mathrm{n}} \quad$ fluid temperature at the point $\mathrm{n},{ }^{\circ} \mathrm{C}$

$\dot{\mathrm{W}} \quad$ work, $\mathrm{kW}$

\section{Greek symbols}

$\varepsilon \quad$ ecological efficiency

$\eta \quad$ efficiency

$\Pi_{\mathrm{g}} \quad$ pollutant indicator

\section{Subscripts}

$\begin{array}{ll}\mathrm{c} & \text { compressor } \\ \mathrm{CO}_{2} & \text { carbon dioxide } \\ \text { comb } & \text { combustible } \\ \text { ele } & \text { electrical } \\ \mathrm{g} & \text { generator }\end{array}$

$\begin{array}{ll}\text { gt } & \text { gas turbine } \\ \text { mec } & \text { mechanical } \\ \mathrm{NO}_{\mathrm{x}} & \text { nitrous oxide } \\ \mathrm{p} & \text { pump } \\ \mathrm{PM} & \text { particulate matter } \\ \text { st } & \text { steam turbine }\end{array}$

\section{INTRODUCTION}

While the efficiency of modern gas turbines varies between 25 and 43\% (BIASI, 2012), the efficiency of combined cycle units is generally near $50 \%$. This makes this technology particularly more attractive from the standpoint of efficiency, since it is possible to generate more power from the energy recycling of the exhaust gases of the gas turbine.

Natural gas is a fossil fuel and its main component is methane $\left(\mathrm{CH}_{4}\right)$. In addition, natural gas is the fossil fuel with more efficient burning and produces less waste. One of the motivations and justifications of this study was the observation of the growing use of natural gas for electricity generation in Brazil. Figure 1 shows the evolution of the use of natural gas as an energy source in Brazil versus the supply of energy, these data collected from the National Energy Balance (2014).

Advances in natural gas consumption can be seen as positive from the environmental point of 
view, since it reduces oil consumption and it is less pollution. Natural gas is richer in hydrogen compared with other fossil fuels; the proportion of carbon dioxide generated by burning is significantly lower.

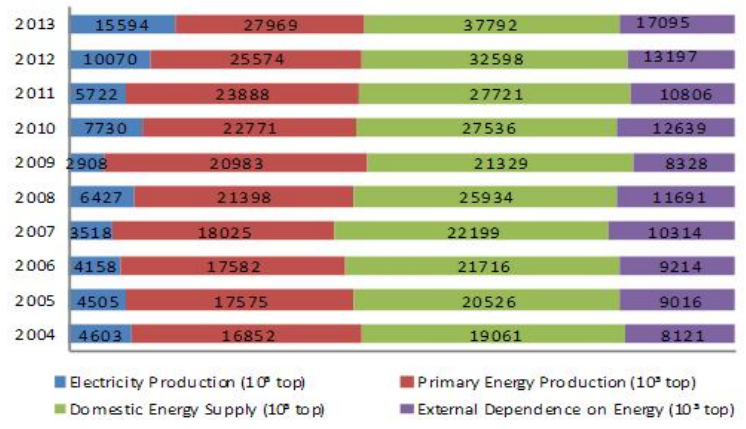

Figure 1. Growing of the use of natural gas for electricity generation by source in Brazil (BEN, 2014).

Natural gas is also considered one of the safest fuels that exist, given its lower density than air, dissipating easily into the atmosphere - unlike, for example liquefied petroleum gas (LPG), which accumulates near the ground in case of leaks. The gas composition used in this study is shown in Table 1.

Table 1. Composition of Gas.

\begin{tabular}{|l|r|r|}
\hline Component & Volume (\%) & $Q_{i}(\mathrm{~kg} / \mathrm{kJ})$ \\
\hline $\mathrm{CO}_{2}$ & 1.50 & - \\
\hline $\mathrm{N}_{2}$ & 0.70 & - \\
\hline Methane $\left(\mathrm{CH}_{4}\right)$ & 89.00 & 50,000 \\
\hline Ethane $\left(\mathrm{C}_{2} \mathrm{H}_{6}\right)$ & 6.00 & 47,525 \\
\hline Propane $\left(\mathrm{C}_{3} \mathrm{H}_{8}\right)$ & 1.80 & 46,390 \\
\hline Butane $\left(\mathrm{C}_{4} \mathrm{H}_{10}\right)$ & 1.00 & 45,775 \\
\hline Total & $\mathbf{1 0 0}$ & $\mathbf{4 7 , 2 2 9 . 4 5}$ \\
\hline
\end{tabular}

The primary air pollutants emitted by thermoelectric units are nitrogen oxides $\left(\mathrm{NO}_{\mathrm{X}}\right)$, sulfur oxides $\left(\mathrm{SO}_{\mathrm{X}}\right)$, volatile organic compounds (VOCs), particulate materials, carbon monoxide $(\mathrm{CO})$, carbon dioxide $\left(\mathrm{CO}_{2}\right)$, methane $\left(\mathrm{CH}_{4}\right)$ and nitrogen dioxide $\left(\mathrm{N}_{2} \mathrm{O}\right)$. Small amounts of organic compounds (hydrocarbons) are released into the atmosphere when the combustion process of the fuel is not completed. Emissions are directly influenced by the type of fuel, combustion technology, size and age of the installation, maintenance procedures and operation. Thus, emission rates increase several orders of magnitude for facilities that are operated with reduced efficiency of the combustion process or unsuitable maintenance (EPA, 1998)

\section{THERMODYNAMIC ANALYSIS}

The analysis on this topic demonstrates through the first law of thermodynamic the amount of heat and electricity generated by the thermoelectric plant investigated as well as its final electrical efficiency.
The first law analysis need to be divided into two stages, first the analysis of the Brayton cycle and then the analysis of the Rankine cycle is performed. In the first cycle, will be analyzed two gas turbines considered identical.

Moran and Shapiro (2006) states that the only ways the energy of a closed system can be changed are through transfer of energy by work or by heat. Further, based on the experiments of Joule and others, a fundamental aspect of the energy concept is that energy is conserved; this is the first law of thermodynamics. These considerations are summarized in the follow equation:

$\left[\begin{array}{l}\text { change in the amount } \\ \text { of energy contained } \\ \text { within the system } \\ \begin{array}{l}\text { during some time } \\ \text { interval }\end{array}\end{array}\right]=\left[\begin{array}{l}\text { net amount of energy } \\ \text { transfered in across the } \\ \text { system boundary by } \\ \text { heat transfer during } \\ \text { the time interval }\end{array}\right]+\left[\begin{array}{l}\text { net amount of energy } \\ \text { transferre d out across } \\ \text { the system boundary } \\ \text { by work during } \\ \text { the time interval) }\end{array}\right]$

This word statement is just an accounting balance for energy, an energy balance. It requires that in any process of a closed system, the energy of the system increases or decreases by an amount equal to the net amount of energy transferred across its boundary. The phrase net amount used in the word statement of the energy balance must be carefully interpreted, for there may be heat or work transfers of energy at many different places on the boundary of a system. At some locations, the energy transfers may be into the system, whereas at others, they are out of the system. The two terms on the right side account for the net results of all the energy transfers by heat and work, respectively, taking place during the time interval under consideration.

The data of the thermoelectric project were provided by the company belonging to the group responsible of the plan. Figure 2 shows a simplified thermoelectric plant cycle proposed for analysis and the Tables 2 and 3 shows the points that will be studied in this work, where:
A- Compressor
B- Gas Turbine
C- Combustion Chambler
D- Heat Recovery Steam Generator
E- High Pressure Steam Turbine
F- Low Pressure Steam Turbine
G- Condenser
H- Pump

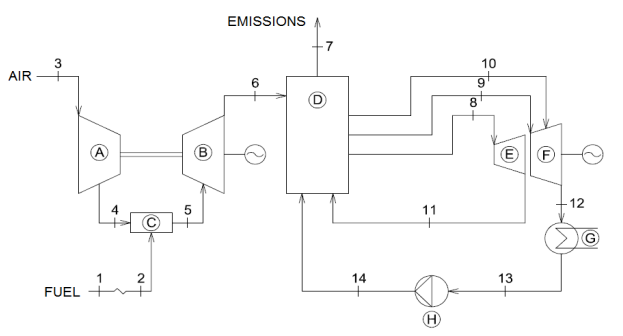

Figure 2. Simplified plant diagram and equipment. 
Table 2. Points of the Brayton cycle.

\begin{tabular}{|c|c|c|c|c|}
\hline Point & $p(\mathrm{MPa})$ & $c_{p}(\mathrm{~kJ} / \mathrm{kg} . \mathrm{K})$ & $T\left({ }^{\circ} \mathrm{C}\right)$ & $\begin{array}{c}\dot{m} \\
(\mathrm{~kg} / \mathrm{s})\end{array}$ \\
\hline 1 & 0.1 & 2.1425 & 25 & 18.22 \\
\hline 2 & 0.1 & 2.6927 & 185 & 18.22 \\
\hline 3 & 0.1 & 1.055 & 25 & 787.88 \\
\hline 4 & 1.381 & 1.0739 & 379 & 787.88 \\
\hline 5 & 1.312 & 1.2096 & 1320 & 806.10 \\
\hline 6 & 0.1 & 1.2293 & 612 & 806.10 \\
\hline 7 & 0.1 & 1.1019 & 86 & 806.10 \\
\hline
\end{tabular}

Table 3. Points of the Rankine cycle.

\begin{tabular}{|c|c|c|c|c|}
\hline Point & $\begin{array}{c}p \\
(\mathrm{MPa})\end{array}$ & $\begin{array}{c}T \\
\left({ }^{\circ} \mathrm{C}\right)\end{array}$ & $\begin{array}{c}\dot{m} \\
(\mathrm{~kg} / \mathrm{s})\end{array}$ & $h(\mathrm{~kJ} / \mathrm{kg})$ \\
\hline 8 & 13.1 & 566 & 96.36 & 3511 \\
\hline 9 & 2.413 & 566 & 110.44 & 3610 \\
\hline 10 & 0.3351 & 292 & 13.67 & 3052 \\
\hline 11 & 2.701 & 340 & 96.36 & 3098 \\
\hline 12 & 0.00728 & 40 & 124.11 & 2358 \\
\hline 13 & 0.00728 & 40 & 124.11 & 167.5 \\
\hline 14 & 14.01 & 42 & 124.11 & 188.2 \\
\hline
\end{tabular}

Table 4 shows the values proportional to the specific heats of each component at each point of the Brayton cycle following Equations shown below.

$$
\begin{gathered}
C_{p 0}=C_{0}+C_{1} \times \theta+C_{2} \times \theta^{2}+C_{3} \times \theta^{3} \\
\theta=\frac{\mathrm{T}}{1000}
\end{gathered}
$$

Table 4. Coefficients for specific heat calculation of perfect gases.

\begin{tabular}{|c|c|c|c|c|}
\hline Gas & $C_{0}$ & $C_{1}$ & $C_{2}$ & $C_{3}$ \\
\hline Methane & 1.20 & 3.25 & 0.75 & -0.71 \\
\hline Ethane & 0.18 & 5.92 & -2.31 & 0.29 \\
\hline Propane & -0.096 & 6.95 & -3.60 & 0.73 \\
\hline Butane & 0.163 & 5.70 & -1.906 & -9.049 \\
\hline Oxygen & 0.88 & -0.0001 & 0.54 & -0.33 \\
\hline Nitrogen & 1.11 & -0.48 & -0.96 & -0.42 \\
\hline Water (g) & 1.79 & 0.107 & 0.586 & -0.20 \\
\hline $\begin{array}{c}\text { Carbon } \\
\text { Dioxide }\end{array}$ & 0.45 & 1.67 & -1.27 & 0.39 \\
\hline
\end{tabular}

Kakaee, Paykani, and Ghajar (2014) explain that the natural gas is a clean burning fuel as compared to the conventional liquid fuels like diesel or gasoline. It has a high octane number and therefore it is suitable for engines with relatively high compression ratio. It has a high self-ignition temperature, so it requires intense source of energy to enable combustion.

$$
\begin{aligned}
& {\left[\begin{array}{l}
0.89 \mathrm{CH}_{4}+0.06 \mathrm{C}_{2} \mathrm{H}_{6}+ \\
+0.018 \mathrm{C}_{3} \mathrm{H}_{8}+0.01 \mathrm{C}_{4} \mathrm{H}_{10}+ \\
+0.015 \mathrm{CO}_{2}+0.007 \mathrm{~N}_{2}
\end{array}\right]_{N G}+} \\
& +\left[4.145 \mathrm{O}_{2}+15.5852 \mathrm{~N}_{2}\right]_{\text {Air }} \rightarrow \\
& \rightarrow\left[\begin{array}{l}
1.119 \mathrm{CO}_{2}+2.082 \mathrm{H}_{2} \mathrm{O}+ \\
+15.5922 \mathrm{~N}_{2}+2.145 \mathrm{O}_{2}
\end{array}\right]_{C G}
\end{aligned}
$$

The combustion reaction with $100 \%$ of air excess provides energy to the cycle and is shown in the Equation 3.

The Table 5 shows the proportion of each gas in each part of the reaction.

Table 5. Proportion of components of gases in this cycle.

\begin{tabular}{|c|c|c|c|c|}
\hline Gas & Formula & $\begin{array}{c}\text { Natural } \\
\text { Gas }\end{array}$ & Air & $\begin{array}{c}\text { Combustion } \\
\text { Emissions }\end{array}$ \\
\hline Methane & $\mathrm{CH}_{4}$ & $89.00 \%$ & - & - \\
\hline Ethane & $\mathrm{C}_{2} \mathrm{H}_{6}$ & $6.00 \%$ & - & - \\
\hline Propane & $\mathrm{C}_{3} \mathrm{H}_{8}$ & $1.80 \%$ & - & - \\
\hline Butane & $\mathrm{C}_{4} \mathrm{H}_{10}$ & $1.00 \%$ & - & - \\
\hline $\begin{array}{c}\text { Carbon } \\
\text { Dioxide }\end{array}$ & $\mathrm{CO}_{2}$ & $1.50 \%$ & - & $5.58 \%$ \\
\hline Nitrogen & $\mathrm{N}_{2}$ & $0.70 \%$ & $21.01 \%$ & $74.99 \%$ \\
\hline Water $(\mathrm{g})$ & $\mathrm{H}_{2} \mathrm{O}$ & - & - & $10.01 \%$ \\
\hline Oxygen & $\mathrm{O}_{2}$ & - & $78.99 \%$ & $9.62 \%$ \\
\hline
\end{tabular}

$$
\begin{gathered}
E_{\text {comb }}=\dot{m}_{2} \times Q_{i} \\
E_{\text {comb }}=860,520.58[\mathrm{~kW}]
\end{gathered}
$$

The energy provided by the fuel to the cycle can be defined by the Equation 4.

Table 6 shows the fixed adopted parameters to the following analysis (Silveira and Tuna, 2003, 2004).

Table 6. Fixed parameters of equipments efficiency.

\begin{tabular}{|c|c|}
\hline Parameter & Efficiency \\
\hline$\eta_{\mathrm{c}}$ & 0.86 \\
\hline$\eta_{\mathrm{mgt}}$ & 0.98 \\
\hline$\eta_{\mathrm{mst}}$ & 0.98 \\
\hline$\eta_{\mathrm{g}}$ & 0.98 \\
\hline$\eta_{\mathrm{p}}$ & 0.9 \\
\hline
\end{tabular}

$$
\begin{array}{r}
\dot{W}_{C}=\frac{\dot{m}_{4} \times\left(\frac{c_{p 3}+c_{p 4}}{2}\right) \times\left(T_{3}-T_{4}\right)}{\eta_{c}} \\
\dot{W}_{C} \cong-338,810.89[\mathrm{~kW}]
\end{array}
$$

The energy consumed by the compressor can be defined by the Equation 5 . 


$$
\begin{aligned}
\dot{W}_{g t}^{m e c} & =\dot{m}_{5} \times\left(\frac{c_{p 5}+c_{p 6}}{2}\right) \times\left(T_{5}-T_{6}\right) \times \eta_{g t} \\
& \dot{W}_{g t}^{\text {mec }} \cong 682,024.16[\mathrm{~kW}]
\end{aligned}
$$

The mechanical energy generated by the gas turbine can be defined by the Equation 6 .

$$
\begin{aligned}
& \dot{W}_{g t}^{\text {ele }}=\left(W_{g t}+W_{c}\right) \times \eta_{g} \\
& \dot{W}_{g t}^{\text {ele }}=329,484.73 \quad[\mathrm{~kW}]
\end{aligned}
$$

The electrical energy generated by the gas turbine cycle can be defined by the Equation 7 .

$$
\dot{W}_{s t}^{\text {mec }}=\left[\begin{array}{l}
\left(\dot{m}_{8} \times h_{8}\right)+\left(\dot{m}_{9} \times h_{9}\right)+\left(\dot{m}_{10} \times h_{10}\right)- \\
-\left(\dot{m}_{11} \times h_{11}\right)-\left(\dot{m}_{12} \times h_{12}\right)
\end{array}\right]
$$

The mechanical energy generated by the steam turbine can be defined by the Equation 8 .

$$
\begin{gathered}
\dot{W}_{s t}^{e l e}=\dot{W}_{s t}^{\text {mec }} \times \eta_{g} \\
\dot{W}_{s t}^{\text {ele }}=173,763.92[\mathrm{~kW}]
\end{gathered}
$$

The electrical energy generated by the steam turbine cycle can be defined by the Equation 9 .

$$
\eta_{\text {ele }}=\frac{\dot{W}_{g t}+\dot{W}_{s t}}{E_{\text {comb }}}=58.25 \%
$$

The electrical efficiency of the plant can be defined by the Equation 10.

\section{POLLUTANT EMISSIONS AND ECOLOGICAL EFFICIENCE}

According Brizi and Silveira (2014), the natural gas is cleaner than fossil fuel oil or coal burning power, and it is believed that the natural gas provides part of the solution to climate change and the problems associated to the poor air quality. Once considered, in large part, a residual product from oil production, the use of natural gas is currently experiencing enormous increase in demand worldwide. As an economically viable and less polluting abundant fuel, natural gas makes sense for developing economies in search of new sources of energy. Unlike coal and oil, natural gas has a higher hydrogen/carbon ratio and emits less carbon dioxide for a given amount of energy consumed. As the cleanest burning fossil fuel, natural gas offers an effective means in terms of immediate cost to improve air quality. Unlike coal and oil, natural gas releases virtually no particulate matter in the atmosphere, which prevents photosynthesis in plants and aggravates heart and lung disease in humans.
Particulate matter is also a contributor to smog. The production and the burning of fossil fuels leads to emissions of nitrogen oxides and sulfur oxides; nitrogen oxides result in many environmental impacts, including pollution and acid rain. Sulfur oxides also contribute to acid rain.

The purpose of this item is to determine the rates of emissions in tons / year of $\mathrm{CO}_{2}, \mathrm{NO}_{\mathrm{X}}, \mathrm{SO}_{2}$ and PM of the thermoelectric plant selected. The second step, is to determine how these pollutants affect the environment by calculating the ecological efficiency. The ecological efficiency assesses how polluter is a thermoelectric plant, considering the combustion of one $\mathrm{kg}$ of fuel, and not the amount of gases released per unit of energy generated.

$$
\begin{aligned}
& a_{1} \mathrm{CH}_{4}+b_{1} \mathrm{C}_{2} \mathrm{H}_{6}+c_{1} \mathrm{C}_{3} \mathrm{H}_{8}+d_{1} \mathrm{C}_{4} \mathrm{H}_{10}+ \\
& +e_{1} \mathrm{C}_{5} \mathrm{H}_{12}+f_{1} \mathrm{CO}_{2}+g_{1} \mathrm{~N}_{2}+h_{1} \alpha \mathrm{O}_{2}+i_{1} \alpha N_{2} \rightarrow \\
& \rightarrow w_{1} \mathrm{CO}_{2}+y_{1} \mathrm{H}_{2} \mathrm{O}+z_{1} \alpha N_{2}+k_{1}(\alpha-1) O_{2}
\end{aligned}
$$

The general chemical formula for combustion of natural gas is described below in Equation 11 (Villela and Silveira, 2007). This equation determines the emission of $\mathrm{CO}_{2}, \mathrm{NO}_{\mathrm{X}}$, Particulate Matter (PM) and $\mathrm{SO}_{2}$.

$$
M=\left[\begin{array}{c}
\left.\begin{array}{c}
16 \times a_{1}+30 \times b_{1}+44 \times c_{1}+58 \times d_{1}+ \\
+72 \times e_{1}+44 \times f_{1}+28 \times g_{1}
\end{array}\right] \\
M=18.21[\mathrm{~kg} / \mathrm{kmol}]
\end{array}\right.
$$

Equation 12 can determine the value of the molar mass of the natural gas to be considered in this study.

The values of the resulting products of combustion of $1 \mathrm{~kg}$ of natural gas can be calculated considering the following emissions shown below in equations 13, 14 and 15 (Villela and Silveira 2007; Carvalho Jr and Lacava, 2003).

$\mathrm{CO}_{2}$ Emissions:

$$
m_{\mathrm{CO}_{2}}=\frac{\left(w_{1} \times 44 \times 1\right)}{M}
$$

\section{$\mathrm{NO}_{\mathrm{X}}$ Emissions:}

Fundamentally comprises nitrogen oxide (NO) and nitrogen dioxide $\left(\mathrm{NO}_{2}\right)$ and are formed in the combustion process due to chemical reaction of oxygen with nitrogen or air in the fuel itself, is generated in all types of electrical power plants that undergo chemical and photochemical reactions in the atmosphere by promoting the formation of troposphere ozone toxic gases, and contribute to respiratory tract and lungs (Saldiva, 1991). For NOx emissions of a fossil fuel plant using natural gas, can be taken a maximum of $15 \mathrm{ppm}$ of $\mathrm{NO}_{\mathrm{X}}$ generated in a dry basis, corrected to $12 \%$ oxygen. A thermoelectric plant using natural gas produces 2270 
$\mathrm{kg}$ of NOx per million cubic meters of fuel. $\mathrm{NO}_{\mathrm{X}}$ emissions may be determined in equation below (Carvalho Jr and Lacava, 2003; Villela and Silveira, 2007).

$$
m_{N O_{X}}=\frac{2.270 \times 22,4 \times 10^{-3}}{M \times 10^{3}}
$$

Particulate matter emission:

According to Braga, Hespanhol and Conejo (2002) particulate matter (PM) are liquid and solid particles of material able to remain suspended in the air, such as dust, soot and oil particles, in addition to the pollen. These particles can be derived from natural activities like volcanoes, pollen dispersal, as well as in combustion processes. The particle diameter plays an important role and efficiency of penetration in the respiratory system can cause coughs, asthma and bronchitis. The emission factor for particulate matter of natural gas is $240 \mathrm{~kg}$ of particulate matter per million cubic meters of fuel rods. Equation below defines these emission values.

$$
m_{P M}=\frac{240 \times 22,4 \times 10^{-3}}{M \times 10^{3}}
$$

$\mathrm{SO}_{2}$ emission:

Issue depends on the amount of sulfur contained in the fuel, is produced during combustion mainly in thermoelectric and diesel oil and coal. In the atmosphere, sulfur dioxide $\left(\mathrm{SO}_{2}\right)$ reacts with water vapor existing in the air and with oxygen to form sulfates and sulfuric acid, causing acid rain (Saldiva, 1991). In this fuel, natural gas, the sulfur concentration is very low and only exists because sulfur is added to the gas so that in case of leaks in gas transmission lines or any plant, leakage can be perceived through the sense of smell. Therefore, its rate of emissions should be invalid.

The Table 7 shows the values of the resulting products of combustion:

Table 7. Resulting products of combustion.

\begin{tabular}{|c|c|}
\hline Emission & Result $\left[\mathrm{kg} / \mathrm{kg}_{\mathrm{NG}}\right]$ \\
\hline $\mathrm{CO}_{2}$ & 2,703 \\
\hline $\mathrm{NO}_{\mathrm{X}}$ & $3,124 \times 10-3$ \\
\hline Particulate Matter & $3,303 \times 10-4$ \\
\hline $\mathrm{SO}_{2}$ & 0 \\
\hline
\end{tabular}

Carbon dioxide equivalent:

$$
\begin{aligned}
& \left(\mathrm{CO}_{2}\right)_{e}=\left(\mathrm{CO}_{2}\right)+80 \times\left(\mathrm{SO}_{2}\right)+50 \times\left(\mathrm{NO}_{X}\right)+67 \times(\mathrm{PM}) \\
& \left(\mathrm{CO}_{2}\right)_{e}=2,88\left[\mathrm{~kg}_{\mathrm{CO}_{2}} / \mathrm{kg}_{\mathrm{NG}}\right]
\end{aligned}
$$

From these data, the emission of carbon equivalent can be obtained by equation 16 .

The following Table 8 shows the estimated mass in tones of pollutant gases, which are issued annually by the thermoelectric plant investigated in steady state that operates $7200 \mathrm{~h}$ per year.

Table 8. Estimated mass of pollutant gases by year.

\begin{tabular}{|c|c|}
\hline Pollutant Emission & Mass (ton/year) \\
\hline $\mathrm{CO}_{2}$ & $1,276,197.12$ \\
\hline $\mathrm{NO}_{\mathrm{X}}$ & $1,474.82$ \\
\hline Particulate Matter & 155.93 \\
\hline$\left(\mathrm{CO}_{2}\right)_{\mathrm{e}}$ & $1,360,385.29$ \\
\hline
\end{tabular}

Cardu and Baica (1999) analyzed the environmental impact of emissions from gas-fired combined cycle, in other words, associations of plants with gas turbines with steam turbines operating in cogeneration system and using fuels: coal, oil and diesel natural gas. In this analysis, we consider emissions of carbon dioxide, nitrogen oxides and sulfur dioxide; furthermore, a comparison of concentrations of each compound of the exhaust gases with specific regulatory standards.

The best fuel from an ecological perspective is the one submitting a minimal amount of carbon dioxide equivalent $\left(\mathrm{CO}_{2}\right)_{\mathrm{e}}$ obtained from burning of it. To quantify this environmental impact defines as "pollution indicator" $\left(\Pi_{\mathrm{g}}\right)$.

$$
\begin{gathered}
\Pi_{g}=\frac{\left(\mathrm{CO}_{2}\right)_{e}}{Q_{i}}=0.06\left[\mathrm{~kg}_{\mathrm{CO}_{2}} / \mathrm{kg}_{\mathrm{NG}}\right] \\
\varepsilon=\sqrt{\left[\frac{0,204 \times \eta_{p}}{\eta_{p}+\Pi_{g}} \ln \left(135-\Pi_{g}\right)\right]} \cong 95.29 \%
\end{gathered}
$$

Ecological efficiency $(\varepsilon)$ is a dimensionless indicator to assess the environmental impact of exhaust emissions from a thermal power plant, by comparing emissions of pollutants integrated hypothetically (equivalent $\mathrm{CO}_{2}$ ) with existing standards of air quality. It is considered the conversion efficiency as a determining factor on the specific, express emissions by a fractional number (Cardu and Baica, 2001). Pollution indicator by (Cardu and Baica, 1999; Villela and Silveira, 2006) and ecological efficiency by (Cardu and Baica, 2001; Villela and Silveira, 2007) are defined by the Equations 17 and 18.

The pollution indicator is a variable which measures the amount of pollution expressed in $\mathrm{kg} / \mathrm{MJ}$, that is, measures the amount of pollution in an energy basis.

\section{RESULTS AND DISCUSSION}

The It was evaluated the environmental impact of parameter called ecological efficiency, which provides a different view on the point of emissions, considering the combustion of $1 \mathrm{~kg}$ of fuel. The analysis applied to a thermoelectric plant operating in combined cycle gas turbines with associated heat 
recovery without supplemental fuel burn and a condensing steam turbine. As expected, through energy analysis was possible to verify that the energy efficiency of the plant is in agreement with the literature studied. According to the adopted standards of the air, it can be seen that the use of natural gas combined cycle technology, is an excellent option under the ecological point of view, in view of the associated environmental impacts levels. According to Villela and Silveira (2007), the natural gas has values of ecological efficiency between $91.6 \%$ and $95.4 \%$ for the system with and without supplemental firing systems respectively. In the case of diesel engines efficiencies are between $89.4 \%$ and $94.1 \%$, then with an ecological efficiency of $95.29 \%$ can be defined that the studied plant is within determined standards.

\section{REFERENCES}

Biasi, V., 2012, Gas Turbine World 2012 Handbook. For project, planning, design, construction and operation, Southport, Pequot Publication.

Braga, B., Hespanhol, I., and Conejo, J. G. L., 2002, Introdução à Engenharia Ambiental, Prentice Hall.

Brizi, F., Silveira, J. L., Desideri, U., Reis, J. A., Tuna, C. E., and Lamas, W. Q., 2014, Energetic and Economic Analysis of a Brazilian Compact Cogeneration System: Comparison between Natural Gas and Biogas, Renewable and Sustainable Energy Reviews, Vol. 38, pp. 193-211.

Cardu, M., and Baica, M., 1999, Regarding a Global Methodology to Estimative the Energyecologic Efficiency of Thermopower Plants, Energy Conversion and Management, Vol. 40, pp. 71-87.

Cardu, M., and Baica, M. A., 2001, A Seismic Vision Regarding a Methodology to Estimative Globally the Energy-Ecologic Efficiency of Thermopower Plants, Energy Conversion and Management, Vol. 42, pp. 1317-1325.

Carvalho Jr, J. A., and Lacava, P. T., 2003, Emissões em Processos de Combustão, Editora UNESP, USBN 85-7139-484-9, 135p. (in Portuguese)

EPA, 1998, U. S. Environmental Protection Agency. "AP-42: Compilation of Air Pollutant Emission Factors. Volume I: Stationary Point and Area Sources. Chapter 1: External Combustion Sources", 5th Edition, USEPA.

Kakaee, A. H., Paykani, A., and Ghajar, M., 2014, The Influence of Fuel Composition on the Combustion and Emission Characteristics of Natural Gas Fueled Engines, Renewable and Sustainable Energy Reviews, Vol. 38, pp. 64-78.

Moran, M. J., and Shapiro, H. N., 2004, Fundamentals of Engineering Thermodynamics, Wiley.

Saldiva, P. H. N., 1991, Efeitos dos Poluentes no Sistema Respiratório, Laboratório de Poluição Atmosférica Experimental, Faculdade de Medicina da USO, Biblioteca da CETESB. (in Portuguese)

Silveira, J. L., and Tuna, C. E., 2003, Thermoeconomic Analysis Method for Optimization of Combined Heat and Power Systems. Part. I, Progress in Energy and Combustion Science, Vol. 29, pp. 479-485.

Silveira, J. L., and Tuna, C. E., 2004, Thermoeconomic Analysis Method for Optimization of Combined Heat and Power Systems. Part. II, Progress in Energy and Combustion Science, Vol. 30, pp. 673-678.

Silveira, J. L., 1998, Uma Contribuição para a Modelagem Termoeconômica: Otimização da Operação e do Projeto de Sistemas Energéticos, Free Job Teaching Thesis, Universidade Estadual Paulista, Guaratinguetá, SP. (in Portuguese)

Silveira, J. L., Carvalho Jr, J. A., and Villela, I. A. C., 2007, Combined Cycle Versus one Thousand Diesel Power Plants: Pollutant Emissions, Ecological Efficiency and Economic Analysis, Renewable \& Sustainable Energy Reviews, Vol. 11, pp. 524-535.

Villela, I. A. C., and Silveira, J. L., 2006, Determinação da Eficiência Ecológica de Plantas Térmicas, in: ENCIT 2006 - 11th Brazilian Congress of Thermal Sciences and Engineering, Curitiba.

Villela, I. A. C., and Silveira, J. L., 2007, Ecological Efficiency in Thermoelectric Power Plants, Applied Thermal Engineering, Vol. 27, pp. 840-847. 